I wish to thank Stuart Houston and Bernie Gollop for reviewing this note.

1 LANE, J., and CHARTIER, B. 1983. A birder's guide to Churchill. L \& P Press, Denver.

2 PETERSON, R. T. 1980. A field guide to the birds east of the Rockies. Houghton Mifflin Co., New York.
3 STOKER, T, 1968. Birds of the Atlantic Ocean. Hamlyn House, Feltham, England.

4 TUCK, G. 1978. A field guide to the seabirds of Britain and the world. Collins, London.

5 WATSON, G. 1966. Seabirds of the tropical Atlantic Ocean. Smithsonian Press, Washington.

\title{
NESTING ROSE-BREASTED GROSBEAKS
}

JEAN BANCROFT, 306-200 Tuxedo Ave., Winnipeg, Manitoba. R3P OR3.

For the past few summers I have observed nests of the Rose-breasted Grosbeak at Whytewold on Lake Winnipeg. In the spring of 1983 a pair of these birds visited our feeder frequently, and eventually a nest was built for the first time on our property.

A male and female came to the feeding tray on 28 May. The fact that these birds continued to appear at the feeder for many days indicated to me that they might be planning to build their nest somewhere close by. It was not until 16 June, however, that I finally discovered the nest. I saw and heard the male singing its soft sweet song from a high branch of a tall oak in our wooded lot. The nest was in a nearby Saskatoon bush. It was approximately $1.8 \mathrm{~m}$ from the ground; the female was sitting. The nest site was surrounded by a thicket of hazelnut. When I made my observations I had to be cautious so as not to disturb these secretive birds.

Unfortunately I did not see the nest being built. Bent states that both male and female take part in its construction; ${ }^{2}$ another authority says the nest is built by the female. ${ }^{5}$ This nest was firmly but loosely built of slender twigs from the hazelnut bushes, and was lined with fine rootlets. I examined the nest after the young fledged and found it true that I could see through it from below. ${ }^{2}$ I could not determine the size of the clutch which varies from 3 to $5 .^{2}$

Several occasions on 17 June I observed the female sitting. In late afternoon the male gave his "tick" call, the female flew up to a high branch on an adjacent tree, and the male gave her a sunflower seed (from our feeder); then he flew down and sat on the nest. She flew away for a respite. Both the male and female incubate. The incubation period is cited as being from 12 to 14 days. ${ }^{5}$

I found it very interesting to watch how both parents shared their duties. The "tick" call was the signal for one or the other to take a turn on the nest; 
one flew off and the other flew on immediately. Generally I was able to tell, by the attendance of one or the other at our feeder, which adult was sitting at a particular time. I visited the nest site frequently and found that until the young had nearly fledged, one parent was always on the nest.

\section{On one occasion (21 June) I} observed the male singing while incubating. This is the habit of some other members of the family Frigillidae, namely, Black-headed Grosbeak and Red-crested (Brazilian) Cardinal. ${ }^{4} 1$

I noticed the adults sat higher on the nest 1 July but I was unable to determine if the chicks had hatched. I continued to observe the nest several times daily, and was convinced, by the posture of the adults on the nest, that they were brooding. On 7 July at 1305 I was fortunate to observe the male feeding the young - 4 necks stretched up. The next day at 1930 no parent was present but I heard a bird in the bushes close by.

On 10 July there were three nearlyfledged young in the nest; one sat up higher and flapped its wings. At 1830 the female came to the feeder, ate of the smaller seeds and flew with some in her beak in the direction of the nest At noon 11 July the nest was empty. The fledgling period appears to conform with the 9 to 12 days cited in literature ${ }^{5}$ Both male and female frequented our feeder until 17 July. They flew in the direction of the nest, however I did not see or hear the fledged young in our wooded lot.

When the female came to our hanging feeder (we had two feeders) she frequently stayed for several minutes. I was able to study her plumage from a distance of about 2.4 $\mathrm{m}$. I was particularly interested because, in the spring of 1978, I had observed and reported what appeared to be a female Black-headed Grosbeak at our feeding tray. ${ }^{3}$ The 1983 female had some of the characteristics of the Black-headed in that her breast and belly were tawny yellow and the markings were heavier on sides of the belly than on the breast. Upvardy states that "the Black-headed hybridizes with its eastern counterpart, the Rose-breasted Grosbeak, along their mutual boundary. ${ }^{6}$ Could it be that the 1983 nesting female was a descendant of the 1978 Black-headed? This particular female had reddish wing linings. Godfrey mentions that "immature males have reddish wing linings", "adult female: similar to young male in first autumn ... but ... wing linings yellow."'4 Forbush states "it seems possible that some birds may not acquire highest plumage until the third year or even later."'2

Every summer brings surprises. I hope that these Rose-breasted Grosbeaks may be able to withstand their long trip to Central America and will return to our garden at Whytewold in 1984. One thing is certain: there will be well-laden feeders awaiting them!

1 BANCROFT, JEAN. 1982. Nesting observations of the Red-crested Cardinal on Oahu. Elepaio 42(7):63.

2 BENT, A. C., and Collaborators. 1968 Life histories of North American cardinals, grosbeaks, buntings, towhees, finches, sparrows, and allies. Part 1. Dover, New York. pp. 37, 43.

3 GARDNER, K. May, 1978. Wild wings. Winnipeg Tribune.

4 GODFREY, W. E. 1966. The birds of Canada. Nat. Mus. Canada, Bull. 203.

5 HARRISON, COLIN. 1978. A field guide to the nests, eggs and nestlings of North American birds. Collins, New York.

${ }^{6}$ UPVARDY, M.D.F. 1977. The Audubon Society field guide to North American birds. Western region. Knopf, New York 